\title{
The development of the tenageer's reproductive health module
}

\author{
Nurwinda Sulistyawati ${ }^{1}$, Daharnis ${ }^{2}$, Yarmis Syukur $^{3}$ \\ ${ }^{123}$ Universitas Negeri Padang, Padang - Indonesia, (windagirl@ymail.com)
}

\begin{abstract}
Adolescence need to understand and maintain their reproductive health However, not all adolescents understand and able to maintain their reproductive health. Therefore it is necessary to reference the maintenance and development of adolescent reproductive health.The purposes of this research are to produce the guidance and counseling moduleabout senior high school teenager's reproductive health which is valid andusable. The method of this research is the development research which used the ADDIE model (Analyze, Design, Development, Implementation, and Evaluation).The subject of this research consists of 6 experts and 40 school counselors. The results of this research show that the guidance and the counseling moduleabout senior high school teenager's reproductive health is valid and usable to be used by school counselor to improve the understanding and prevent the problems in teenager's reproductive.
\end{abstract}

Keywords: teenager's reproductive health, guidance counseling, module, high school student.

\section{Introduction}

Adolescence, age range 12-22 years is a period of development from children to adults characterized by physical and psychological changes (Pane, Mudjiran, \& Daharnis, 2016; Direktorat Bina Ketahanan Remaja, 2014; Yendi, 2014; Sarwono, 2012). Physical changes, with regard to physical growth, functioning of reproductive organs, and other secondary sexual influences on the development of teenage psyche. In relation to these changes and developments, there are several key features of adolescence, that is, the primary features of organs relating to the process of reproduction, secondary features are physical signs associated with reproductive functions and systems, which distinguish between men and women, and tertiary features are related to psychic changes that occur in adolescents (Kurniadi, 2017; Yuda, 2017; Soejanto, 2005).

During its growth and development, adolescents experience problems that result from changes caused by the maturation of reproductive organs that are often unknown. The problem of reproduction is one of the highest problems in terms of youth health and well-being; reproductive health issues affecting a teen's sexual health and sexual health are important components of reproductive health (Fatusi, 2016; Zhagan 2013). Problems arising from reproductive health can lead to sexual problems or the consequences of sexuality. In addition to these problems, reproductive health problems can lead to more serious, if behaviors that do not maintain reproductive health 
health leading to Sexually Transmitted Infections (IMS) and Human Immunodeficiency Virus (HIV)/Acquired Immuno Deficiency Syndrome (AIDS) (Aisyaroh, 2018; Bil, Hoornenborg, Prins, Hogewoning, Dias Goncalves Lima, De Vries, \& Davidovich, 2018).

Studies conducted by interviewing counselors in one of the high schools and teenager's of Bengkulu City on 10-11 January 2017 that there are still students who feel shy and considered taboo to ask and tell the problem of reproductive health, even their parents are still a lot of less attention to health reproduction of children, so that students are not familiar with reproductive health. Such misunderstanding can cause problems beyond the norm, such as kissing cheeks, lips, and sexual relationships, even BKKBN declares teenager's 13-22 years in Bengkulu province there are peddling and having free sex with girlfriends and abortions (Muadz, 2013). It is without them knowing it can damage the reproductive organs.

Understanding teenager's Bengkulu about reproductive health is limited to the theory, teenager's have not really understand the importance of maintaining reproductive health. The teenager's expect sources of information that can provide an understanding of the need for hygiene maintenance of reproductive organs, reproductive processes, and the impact of irresponsible behavior that can lead to reproductive health problems. Based on the emerging phenomenon related to teenager's reproductive health problem, it is important for teenager's to get correct reproduction health information as early container of sex education for teenager's.

\section{Method}

The method of this research is development research which used the ADDIE model that is Analyze, Design, Development, Implementation, and Evaluation (Personal, 2011; Mudjiran, 2011). The subject of this research consists of 6 experts and 40 school counselors.Instruments using Questionnaire and Focus Group Discussion (FGD). The data were analyzed by using statistics descriptiveand to measure the degree of alignment/consistency in validation test using coefficient of concordance kendall test and alignment/consistency in usabletest using coefficient of alpha cronbach test.

\section{Results and Discussion}

\section{Product Development}

The developed product is guidance along with the guidance and counseling module of senior high school teenager's reproductive health. Guidelines devoted to counselors are used to guide students in the use of modules with respect to some aspects of the guidelines such as objectives, success indicators, timing, activity formats, tools, implementation and evaluation steps.

The module was developed to become a learning medium for counselors in providing services to high school students, designed based on the students' needs regarding reproductive health. The module uses students' easy-to-understand language with an eye-catching display of materials: 1) recognizing teenager's, 2) reproductive health, 3) how to maintain reproductive health, 4) reproductive health myths, and 5) responding to reproductive health issues. 


\section{Product Development Test}

\section{Product Validation Test by Experts}

Table 1. Product Validation Test Results by Experts

\begin{tabular}{|c|l|c|c|c|}
\hline No & \multicolumn{1}{|c|}{ Aspect } & Mean & Mean (\%) & Category \\
\hline 1 & Usability of module & 4.00 & 80 & Valid \\
\hline 2 & General Instruction of module & 3.92 & 78 & Valid \\
\hline 3 & Content of module & 4.03 & 81 & Valid \\
\hline 4 & Target of module & 4.25 & 85 & Valid \\
\hline 5 & Service Planning & 4.13 & 83 & Valid \\
\hline 6 & Layout & 3.43 & 69 & Quite Valid \\
\hline 7 & Language & 4.33 & 87 & Very Valid \\
\hline 8 & Presented material & 4.23 & 85 & Valid \\
\hline \multicolumn{2}{|c|}{ Total } & $\mathbf{4 . 0 1}$ & $\mathbf{8 0}$ & Valid \\
\hline
\end{tabular}

Based on Table 1, the experts provide a valid assessment of the developed product and there is alignment/consistency assessment of the 6 experts through the coefficient of concordance kendall test shown with the value of kendall's Wa 0.265, Chi-square Calculate 55.673 at Asymp. Sig. 0.05.

\section{ProductUsableTest by Counselors}

Tabel 3. ProductUsable Test Results by Counselors

\begin{tabular}{|c|l|c|c|c|}
\hline No & \multicolumn{1}{|c|}{ Aspect } & Mean & Mean (\%) & Category \\
\hline 1 & Planning & 4.04 & 81 & High \\
\hline 2 & Implementation & 4.10 & 82 & High \\
\hline 3 & Evaluation & 4.10 & 82 & High \\
\hline \multicolumn{2}{|c|}{ Total } & 4.08 & 82 & High \\
\hline
\end{tabular}

Based on Table 3, the Counselors gave a high assessment of the product and there was alignment/consistency assessment of the 40 Counselors through thecoefficient of alpha cronbach test shown with coefficient $>0.80(0.920>0.80)$.

\section{Level of Product Validation}

The resultingresearch product is an addiction with the guidance and counseling module of senior high school teenager's reproductive health. The result of the research can be seen that the module compiled reached the valid category with the average percentage of $80 \%$ of the ideal score with the consistency/alignment level of coefficient of concordance kendall between experts 55.673. The assessment is based on content objectivity/content in the module. The findings of this study in accordance with research Yendi (2014) on the Development of Guidance and Counseling Module for Prevention of Free Sex Behavior in Early Youth states that, the validation of a module developed can be known if the module meets one of the characteristics of self contained.

Sukiman (2012) explains that the module is said to be self contained if all the required learning materials are contained in one module intact, so that the developed reproduction health counseling and counseling module can give high school teenager's a chance to comprehend the material thoroughly because the material is packed into one unified whole. In this case, the assessment given by the expert on the 8 aspects that isusability of module, general instruction of module, content of module, target of module, service planning, layout, language, and presented material, none of which indicates the assessment below is valid. 
Based on the description, it is found that the guidance product along with the guidance and counseling module of senior hight school teenager's reproductive health can be used by counselors in providing services to students to improve understanding and prevent the problems in teenager's reproductive.

\section{Level of Product Usable}

Level usable product of the guidance and counseling module of senior high school teenager's reproductive health by counselors in providing services to achieve high category. The average percentage of counselors appraisal $82 \%$ of ideal score with conformity/consistency coefficient of alpha cronbach 0.920, it can be interpreted that counselors can use the module well, it is seen from the aspect of Planning, implementation, and evaluation reached the high category. This is relevant to the opinion of Daryanto (2013) which states that, the module is one form of teaching materials that contains the objectives of learning, materials, methods, limitations, and how to evaluate systematically designed and interesting to achieve the expected competencies.

The results of this development in accordance with the opinionKowitlawakul, Chan, Tan, Soong, \& Chan (2017) states that, the module developed is in accordance with the characteristics of the module self-instruction. Sukiman (2012) states that self instruction allows students to learn independently and not depend on others. The use of this module also leads the students to find their own concepts, so that the service using the module will be more focused on the students while the counselors only function as facilitator. Thus, the guidance and counseling module of senior high school teenager's reproductive health is expressed by counselors assist students in maintain reproductive health and avoid the problems reproductive health.

\section{Conclusions}

Based on the results of research, then drawn some conclusions, as follows:

1. Products developed in the guidance and counseling module of senior high school teenager's reproductive health. As a medium for students to gain an understanding and prevention of reproductive health problems, designed based on the needs of students with 5 subject matter in the discussion using the language that is easy to understand and the look of interest.

2. The guidance and counseling module of senior high school teenager's reproductive health is substantively valid, covering the aspects usability of module, general instruction of module, content of module, target of module, service planning, layout, language, and presented material.

3. The usable level of the guidance and counseling module of senior high school teenager's reproductive health is considered high, counselors have no difficulty using the module as a medium in guidance and counseling services ranging from planning, implementation, until evaluation.

Several suggestions are proposed, among others: 1) Counselors can use the module in guidance and counseling services to improve understanding relating to the signs of teenager's development on reproductive health. 2) The principal can facilitate the module as a medium in school, so that teenager's better understand the conditions in themselves so as to maintain good reproductive health, and the media is also a source of reference for counselors and subject teachers. 3) Parents can use the module as the implementation of sex education for children at home, so that children can understand and maintain their reproductive health. 4) Other researchers can refine this research by conducting field trials to see the effectiveness of the module, developing the materials in the module or developing other media to support the use of counseling modules and reproductive health counseling for teenager's senior high school. 


\section{Acknowledgments}

The researcher would like to thank all parties who have helped during the research process, giving suggestions and contributions to the refinement of research results, as well as support both motivation, morale, moral and material encouragement in the results of this study.

\section{References}

Aisyaroh, N. (2018). Upaya Preventif Permasalahan Kesehatan Reproduksi Perempuan Lapas (Hasil Pengabdian Masyarakat Penyuluhan Kesehatan Reproduksi dan Pemeriksaan Pap di Lembaga Pemasyarakatan (Lapas) Kelas IIA Perempuan Semarang). Majalah Ilmiah Sultan Agung, 50(126), $1-13$.

Bil, J., Hoornenborg, E., Prins, M., Hogewoning, A., Dias Goncalves Lima, F., De Vries, H. J. C., \& Davidovich, U. (2018). The acceptability of pre-exposure prophylaxis: beliefs of healthcare professionals working in sexually transmitted infections clinics and HIV treatment centers. Frontiers in Public Health, 6, 5.

Daryanto. (2013). Menyusun Modul Bahan Ajar Untuk Persiapan Guru Dalam Mengajar. Yogyakarta: Gava Media.

Direktorat Bina Ketahanan Remaja. (2014). Pedoman Pengelolaan Pusat Informasi dan Konseling Remaja dan Mahasiswa (PIK R/M). Jakarta: Badan Kependudukan Keluarga Berencana Nasional.

Fatusi, A. O. (2016). Young People's Sexual and Reproductive Health Interventions in Developing Countries: Making the Investments Count. Journal of Adolescent Health, 59(3), S1-S3.

Kowitlawakul, Y., Chan, M. F., Tan, S. S. L., Soong, A. S. K., \& Chan, S. W. C. (2017). Development of an e-Learning research module using multimedia instruction approach. CIN: Computers, Informatics, Nursing, 35(3), 158-168.

Kurniadi, D. (2017). Peranan Lembaga Adat Dalam Mengatasi Kenakalan Remaja di Desa Lebaksiuh Kabupaten Sumedang (Studi Deskriftif di Desa Lebaksiuh kabupaten Sumedang) (Doctoral dissertation, FKIP UNPAS).

Muadz, M., dan Febrianti, C. A. (Eds.). (2013). Penyiapan Kehidupan Berkeluarga Bagi Remaja. Bengkulu: Perwakilan Badan Kependudukan dan Keluarga Berencana Nasional Provinsi Bengkulu.

Mudjiran. (2011). Pengembangan Model Penugasan Terstruktur Kepada Siswa. Padang: Sukabina Press.

Pane, R. M., Mudjiran, M., \& Daharnis, D. (2016). Pengembangan Modul Bimbingan dan Konseling untuk Pencegahan Perilaku Seksual Pranikah Siswa Sekolah Menengah Atas (SMA). Konselor, 3(3), 122-127.

Pribadi, B. A. (2011).Model Desain Sistem Pembelajaran. Jakarta: Dian Rakyat.

Soejanto, A. (2005). Psikologi Perkembangan. Jakarta: Rineka Cipta.

Sukiman. (2012). Pengembangan Media Pembelajaran. Yogyakarta: Pedagogia.

Yendi, F. M. (2014). Pengembangan Modul Bimbingan dan Konseling untuk Pencegahan Perilaku Seks Bebas pada Remaja Awal. (Tesis tidak diterbitkan). Program Studi S2 Bimbingan dan Konseling Program Pascasarjana Fakultas Ilmu Pendidikan Universitas Negeri Padang.

Yuda, P. Z. (2017). Upaya Kepolisian dalam Menanggulangi Tindak Pidana Perjudian yang Dilakukan oleh Remaja di Wilayah Hukum Kepolisian Resor Kota Padang (Doctoral dissertation, Universitas Andalas).

Zhagan, M. (2013). Understanding of Parents and Adults on the Down Syndrome Female Sexual Reproductive Health. Malaysian Online Journal of Educational Sciences, 1(4), 48-56. 